But the lack of openness creates the opportunity for injustice, and although the decision can be appealed, a reversal in court does not necessarily guarantee reinstatement. A lengthy backlog of pending cases means that most of the vacated jobs will already have been filled. Even if reinstatement were offered, a lingering hostility may make working conditions intolerable. A more likely outcome of a successful appeal is monetary compensation.

In Sachsen, with the highest concentration of higher education institutes, about 1,000 academic staff have been dismissed for reasons of 'personal integrity'; nearly half have already left. Leipzig-based solicitor Karl Bönninger estimates that half of those dismissed are taking legal action, but so far no cases have been resolved in court, and in most cases the court hearing will be delayed for so long that the posts will be filled and the only recompense will be monetary.

In Sachsen-Anhalt, about 250, a quarter of the total redundancies, have been for political offences. Half are thought to be appealing their dismissal. Specific numbers in other states are not available, but in Thüringen around 250 people are likely to be involved, at least a third of whom may be seeking legal redress.

Although the restructuring of universities should have been completed within two years, it has been extended for a third year and may take even longer. To date, only one appeal has been completed, with the court finding in favour of the appellant.

Hans-Ulrich Mönnig, lodged a successful appeal against his dismissal as rector and professor at the University of Architecture and Civil Engineering in Weimar, Thüringen, although the state minister of research, Ulrich Fickel, fought unsuccessfully to overturn the ruling. Despite the experience, a result of a poor personal relationship between the two men, Mönnig believes that commissions are necessary to remove Stasi collaborators from public office and that the courts are capable of ensuring that justice prevails. At the same time, he thinks that the hearings and decisions should be open to public scrutiny and that the proceedings should be monitored by a qualified jurist.

\section{Alison Abbott}

\section{Max Planck opens marine institute}

Munich. The Max Planck Society, which funds science research institutes throughout Germany, this month opened its 57th variety - the Max Planck Institute for Marine Microbiology in Bremen. The new institute has two directors, and by 1996 plans to have a staff of 100 , including 20 scientists. The research will focus on bacterial processes in marine environments.

Alison Abbott

\title{
Chinese scientist arrested for entrepreneurial spirit
}

Beijing. A Chinese scientist was arrested and thrown in jail for seven days by local authorities for his role in running a factory based on a product invented in his laboratory. The incident, which occurred in July, reflects the considerable hostility in parts of the country towards efforts by Communist Party leaders to support high-technology enterprises as a way of strengthening the nation's economy.

Zhang Shu-Lin, the 52-year-old director of the Jingzhou Kangbao New Technology Research Institute in Hubei Province in central China, visited Xiangfan City in Hubei to meet officials from the local hightechnology development bureau planning a factory to manufacture a powerful detergent he had developed in his laboratory. Zhang had created a similar business in 1987 in cooperation with one of the city's neighbourhood committees, but Fandong government officials were jealous of the factory and after three years their opposition forced Zhang to quit as manager and bankrupted the company.

Since then, the State Science and Technology Commission has begun to encourage scientists to pursue commercially useful ideas, increasing government funding for such efforts. But its campaign has met with mixed success in much of the countryside outside the capital and selected enterprise zones in southern China. In those regions, the legacy of the 10-year Cultural Revolution, with its fervent anti-intellectualism, remains strong.

That attitude, combined with concern that the new factory posed unwanted com- petition for local state-run enterprises, apparently led to Zhang's arrest on 3 July. Forcibly dragged from his temporary residence by Fandong District police, Zhang was handcuffed and paraded through the streets of the city amidst taunts of being "a stinking intellectual and an inventor".

While in prison, Zhang learned that his arrest resulted from an audit of his factory conducted two years earlier that had angered local authorities. Fortunately for Zhang, his situation was brought to the attention of the State Science and Technology Commission in Beijing, which managed to win his release on 10 July.

"This case is an example of what can happen when someone takes advantage of the increased opportunities for commercial activity in China and incurs the envy and anger of local officials", says Richard Dicker, a lawyer with Human Rights Watch in New York. "It offers a small but chilling insight into the many restrictions that exist on scientific activity in China."

The incident might have escaped notice had not the local party chief, Yang BingQing, learned about Zhang's arrest a few weeks later. Yang promptly apologized to Zhang and promised to pursue those responsible. An investigation is continuing.

The Chinese press have decried the episode as demonstrating how much remains to be done to sell the government's message that the nation respects scientific talent and the fruits of its labour. Clearly, what is needed is an ongoing educational campaign about the value of knowledge.

You Qin Li

\section{Scavengers undermine Indian incinerator}

New Delhi. India's legions of rag-pickers have foiled the country's first waste incineration plant, causing it to close without having produced any electricity. The government is seeking $\$ 10$ million in damages from $\mathrm{M} / \mathrm{S}$ Volund, the Danish contractor responsible for designing, building and operating the plant.

The waste plant, commissioned in 1988 , was designed to generate $4 \mathrm{MW}$ of electricity by burning 300 tonnes of waste daily. But neither the government nor the contractor took into consideration Delhi's 8,000 ragpickers, who systematically retrieve reusable items such as wood, plastics, paper and cloth from municipal landfills. Unfortunately, once such combustible garbage is removed, the remains - mostly rotten vegetables and cooking wastes that do not easily burn - are not sufficient to operate the plant.
The Danish company was supposed to operate the plant for one year before handing it over to India's Department of Nonconventional Energy Sources (DNES), but engineers tried unsuccessfully for 18 months to get the plant working. DNES officials say that the company's engineers tested the quality of Delhi's garbage and found it adequate, and the government has asked for $\$ 10$ million to recover its investment.

Apart from the issue of the garbage, environmentalists have opposed the plant because it does not contain a flue-gas cleaning system to reduce levels of dioxin being emitted. The Danish company has been criticized for ignoring the fact that several municipal incinerators emitting high levels of dioxin were shut down in the Netherlands at the same time as the contract with India was being negotiated.

K.S. Jayaraman 